\title{
Enhancement of accelerated carbonation of alkaline waste residues by ultrasound
}

\author{
Paris K. Araizi *, Colin D. Hills, Alan Maries, Peter J. Gunning, David S. Wray \\ Faculty of Engineering and Science, University of Greenwich, Chatham Maritime, Kent ME4 4TBUK, United Kingdom
}

\section{A R T I C L E I N F O}

\section{Article history:}

Received 8 June 2015

Revised 15 December 2015

Accepted 6 January 2016

Available online 19 February 2016

\section{Keywords:}

Accelerated carbonation

Ultrasound

Carbon sequestration

Waste disposal

Alkaline residues

\begin{abstract}
A B S T R A C T
The continuous growth of anthropogenic $\mathrm{CO}_{2}$ emissions into the atmosphere and the disposal of hazardous wastes into landfills present serious economic and environmental issues. Reaction of $\mathrm{CO}_{2}$ with alkaline residues or cementitius materials, known as accelerated carbonation, occurs rapidly under ambient temperature and pressure and is a proven and effective process of sequestering the gas. Moreover, further improvement of the reaction efficiency would increase the amount of $\mathrm{CO}_{2}$ that could be permanently sequestered into solid products.

This paper examines the potential of enhancing the accelerated carbonation of air pollution control residues, cement bypass dust and ladle slag by applying ultrasound at various water-to-solid (w/s) ratios. Experimental results showed that application of ultrasound increased the $\mathrm{CO}_{2}$ uptake by up to four times at high $\mathrm{w} / \mathrm{s}$ ratios, whereas the reactivity at low water content showed little change compared with controls. Upon sonication, the particle size of the waste residues decreased and the amount of calcite precipitates increased. Finally, the sonicated particles exhibited a rounded morphology when observed by scanning electron microscopy.
\end{abstract}

(c) 2016 Published by Elsevier Ltd.

\section{Introduction}

With approximately $36 \mathrm{Gt}$ of $\mathrm{CO}_{2}$ emitted globally every year, the adverse impact of human activity on global climate is now beyond doubt (Parmesan et al., 2013; Power et al., 2013). Cement manufacture, processing of steel and iron as well as incineration of municipal solid wastes are some examples of carbon-intensive processes that need to be controlled in order to reduce the concentration of $\mathrm{CO}_{2}$ into the atmosphere (Bobicki et al., 2012).

In addition, the disposal of millions of tonnes of hazardous waste into landfills presents serious implications for human health and the environment due to the release of heavy metals and harmful contaminants (Nabhani et al., 2013; Cárdenas-Escudero et al., 2011). Carbon emissions mitigation and waste management could be simultaneously realised by reacting $\mathrm{CO}_{2}$ with waste residues via a process known as accelerated carbonation (AC). Accelerated carbonation involves the reaction of alkaline wastes or cementitius materials with pure or flue gas-derived $\mathrm{CO}_{2}$, ideally from the same plant, to produce stable mineralised products (Gunning et al., 2010; Castellote et al., 2008; Goñi and Guerrero, 2003; De Ceukelaire and Van Nieuwenburg, 1993).

\footnotetext{
* Corresponding author.

E-mail address: P.K.Araizi@greenwich.ac.uk (P.K. Araizi).
}

The use of AC decreases the alkalinity and toxicity of several wastes by reducing the $\mathrm{pH}$ and concentration of heavy metals such as cadmium (Cd), chromium ( $\mathrm{Cr}$ ), lead $(\mathrm{Pb})$ and zinc $(\mathrm{Zn})$ (Rendek et al., 2006; Pérez-López et al., 2008), and provides manufacturing with lower-cost options for the management of solid wastes in countries with expensive landfill taxes (Shu-Yuan et al., 2012). Also, accelerated carbonation facilitates waste valorisation, which may lead to the formation of products that could be used for civil engineering purposes (Gunning et al., 2009).

Candidate residues for AC include air pollution control residues (Tian and Jiang, 2012; Li et al., 2007; Zhang et al., 2008; Prigiobbe et al., 2009), cement dusts (Huntzinger et al., 2009a) and steelmaking slags (Huijgen and Comans, 2005; Boone et al., 2013). These residues are found in large quantities around the world and as such, they have potential to sequester significant amounts of $\mathrm{CO}_{2}$ under low temperature and pressure (Renforth et al., 2011; Kirchofer et al., 2013).

The efficiency of accelerated carbonation is quantified by the $\mathrm{CO}_{2}$ uptake, which is a function of the initial and final $\mathrm{CO}_{2}$ concentration and can be measured by calorimetric or thermogravimetric analysis (Baciocchi et al., 2009).

$$
\mathrm{CO}_{\text {2UPTAKE }} \%=\frac{\mathrm{CO}_{2 \text { FINAL }} \%-\mathrm{CO}_{\text {2INITIAL }} \%}{100-\mathrm{CO}_{\text {2FINAL }} \%} * 100
$$


Ambient temperature and pressure are preferable during $A C$ in order to keep the associated costs to a minimum. Previous workers estimated the maximum $\mathrm{CO}_{2}$ uptake of air pollution control residues (APCr) at 20\% (Cappai et al., 2012), cement dusts at $11.5 \%$ (Huntzinger et al., 2009b) and steel-slags at 28.3\% (Chang et al., 2013), by using various carbonation methods and reactors. The application of cost-effective techniques for enhancing the carbonation efficiency will increase the carbon sequestration capacity of these residues allowing more $\mathrm{CO}_{2}$ to be bound into the products (Sanna et al., 2012). The application of ultrasound, also known as sonication, is a physical technique with potential to improving the reaction efficiency.

The main effect of sonication is cavitation, or the formation, development and collapse of small bubbles in liquids, resulting in high temperatures and pressures, while water acts as the aqueous medium, permitting efficient energy transmission between the ultrasonic device and the solid to be treated (Rao et al., 2007).

Sonication is known to increase the precipitation rate of calcium carbonate from mineral substrates (Nishida, 2004; Kojima et al., 2010; López-Periago et al., 2011; Santos et al., 2012, 2010; Stoica-Guzun et al., 2012), enhance the dissolution rate of $\mathrm{CO}_{2}$ in water (López-Periago et al., 2010), decrease particle size (Lu et al., 2002; Rao et al., 2007; Kojima et al., 2010; Santos et al., 2010) and increase the dissolution rate of sonicated solids especially for particles with a low surface area (Lu et al., 2002). Important features of sonication are the time of treatment, size of sample, power of the ultrasonic device and temperature (Franco et al., 2004). A previous study on particle breakage phenomena suggested that higher sonication power facilitated cavitation, while longer sonication times resulted in enhanced particle breakage in the temperature range $25-37{ }^{\circ} \mathrm{C}$ (Raman and Abbas, 2008).

The literature reports several studies on sonication of wastes (Rao et al., 2007; Santos et al., 2010, 2013a; Said et al., 2015), but none of them examines the effects of this technique upon the $\mathrm{CO}_{2}$ uptake at low $\mathrm{w} / \mathrm{s}$ ratio. Also, except for steel-slag and fluidised bed combustion (FBC) ash, no other alkaline waste was tested.

The main objective of this paper was to examine whether sonication increases the $\mathrm{CO}_{2}$ uptake of $\mathrm{APCr}$, cement bypass dust (CBD) and ladle slag (LS) at low, medium and high $\mathrm{w} / \mathrm{s}$ ratios under ambient temperature and pressure. In addition, the effects of sonication on particles size, mineral composition and morphology of the treated materials were studied by using appropriate analytical techniques.

\section{Materials and methods}

\subsection{Materials and preparation}

$500 \mathrm{~g}$ of each waste were received as finely grained powders. $\mathrm{APCr}$ coming from the incineration of municipal solid wastes (MSW) were received from Slough Heat and Power; CBD from Cemex Rugby Plant and ladle slag (LS) from Harsco Sweden. Before treatment the waste powders were dried in oven at $105^{\circ} \mathrm{C}$ for $24 \mathrm{~h}$ and then cooled in a desiccator for 30 min. Ordinary Portland cement (CEM 1) $42.5 \mathrm{~N}$ was obtained from Cemex and used for apparatus testing and calibration.

\subsection{Accelerated carbonation of residues}

After preparation, $0.5 \mathrm{~g}$ of solid was placed inside plastic containers (volume $50 \mathrm{ml}$ ) and mixed with distilled water at the selected $\mathrm{w} / \mathrm{s}$ ratios $(0.2,0.4,0.6,0.8,1,5,10,25,50$ and 100). Then, the mixes were carbonated, without agitation, for $1 \mathrm{~h}$ by using the experimental set-up (closed system) shown in Fig. 1. The set up consisted of: (a) a $\mathrm{CO}_{2}$ chamber containing carbon dioxide gas of $99.9 \%$ purity, (b) a rota-meter to measure/control the flow of $\mathrm{CO}_{2}$ into the system, (c) an aspirator to humidify the incoming gas, (d) a water-bath capable of generating an ultrasonic field at $35 \mathrm{kHz}$ and containing up to 10 sealed plastic tubes connected in series, and (e) a condenser to maintain the temperature constant.

\subsection{Sonication at $35 \mathrm{kHz}$}

The same mixes were sonicated, without agitation, for $1 \mathrm{~h}$ by using an ultrasonic bath at $35 \mathrm{kHz}$ (Camlab, power rating $150 \mathrm{~W}$ ). The selection of ultrasonic bath, instead of ultrasonic probe, was made in order to examine the effect of sonication on various water concentrations including low $\mathrm{w} / \mathrm{s}$ ratio samples. The input power delivered to the system was found to be $120 \mathrm{~W}$. Thus, the energy consumption of the device was estimated at $0.12 \mathrm{~kW}$ h. The attenuation of sound waves was tested by sonicating CEM 1 inside plastic and Pyrex containers. The results showed that the average $\mathrm{CO}_{2}$ uptake of CEM 1 inside the plastic tubes was higher compared to Pyrex.

For each residue, the samples that showed the highest $\mathrm{CO}_{2}$ uptake were sonicated over a prolonged time (up to $8 \mathrm{~h}$ ) in order to determine when the rate of sonication stops progressing.

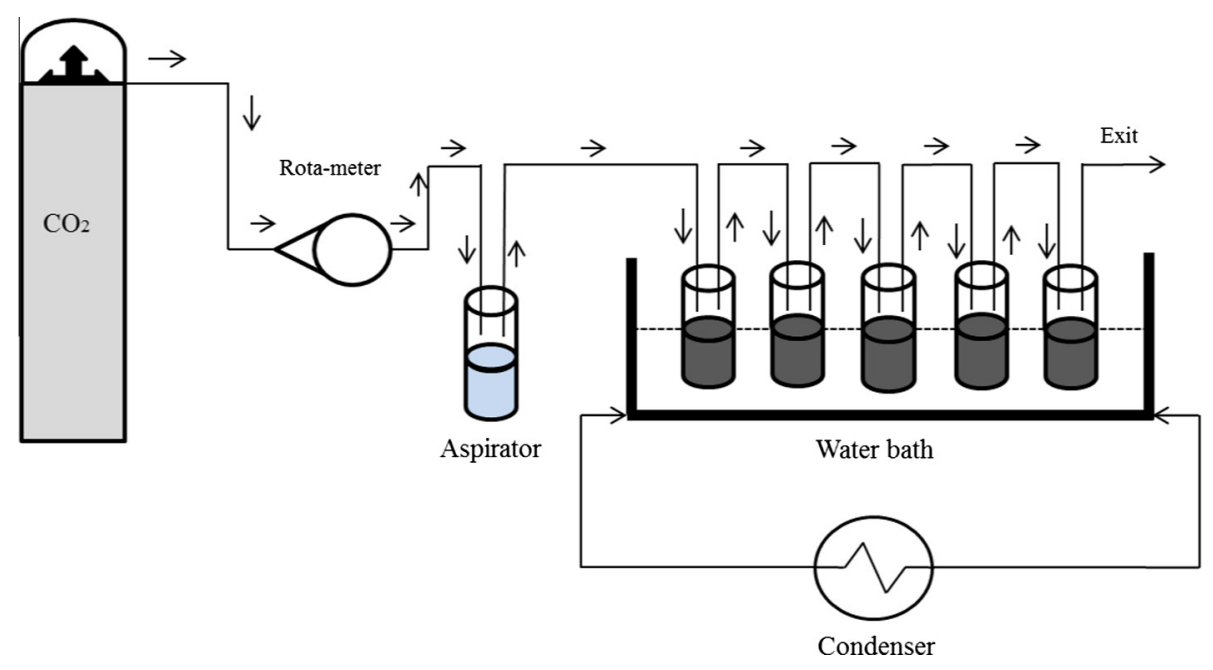

Fig. 1. Experimental set up. 
Table 1

Key parameters of the particle size distribution for the un-treated materials.

\begin{tabular}{lllrlc}
\hline Material & $\begin{array}{l}d(0.1) \\
(\mu \mathrm{m})\end{array}$ & $\begin{array}{l}d(0.5) \\
(\mu \mathrm{m})\end{array}$ & $\begin{array}{l}d(0.9) \\
(\mu \mathrm{m})\end{array}$ & $\begin{array}{l}\text { Specific } \\
\text { surface area } \\
\left(\mathrm{m}^{2} / \mathrm{g}\right)\end{array}$ & $\begin{array}{l}\text { Volume weight } \\
\text { mean diameter } \\
(\mu \mathrm{m})\end{array}$ \\
\hline APCr & 2.6 & 10.7 & 293.1 & 1.23 & 72.2 \\
CBD & 2.5 & 24.1 & 154.9 & 1.10 & 55.0 \\
Steel slag & 2.7 & 85.0 & 325.9 & 0.87 & 125.3 \\
CEM 1 & 2.7 & 19.0 & 86.0 & 1.10 & 38.3 \\
\hline
\end{tabular}

All experiments were conducted at $T=20^{\circ} \mathrm{C}, p=1$ bar and $\mathrm{CO}_{2}$ flow-rate $=0.2 \mathrm{~L} / \mathrm{min}$ and repeated in triplicate

\subsection{Analytical techniques}

The chemical composition of the input materials was analysed by X-ray fluorescence (XRF) on a Bruker S4 Explorer and each analysis lasted for $15 \mathrm{~min}$. The mineral phases of the un-treated and treated materials were identified by X-ray diffraction (XRD) by using a Bruker D8 Advance and by analysing the samples between $5^{\circ}$ and $65^{\circ} 2 \theta$ in $0.02^{\circ}$ steps each lasting $0.4 \mathrm{~s}$. Particle size with and without ultrasound was estimated by wet laser diffraction on a Malvern Mastersizer MS2000 by utilising the wet sample delivery module (Hydro $\mathrm{MU}$ ). The $\mathrm{CO}_{2}$ uptake of the treated materials was measured by an IL 550 TOC-TN/DSC1300 analyser (Hash Lange UK), calibrated with $\mathrm{CaCO}_{3}$ (99\% purity). The microstructures of the sonicated and non-sonicated samples were examined by a JEOL JSM-5310LV, using secondary electrons.

\section{Results and discussion}

\subsection{Materials characterisation}

The key statistical parameters (10th, 50th, 90th percentiles, specific surface area and mean volume) of the particle size distribution of the raw materials are presented in Table 1. CEM 1 displayed the finest particles with $d(0.5)=19.0 \mu \mathrm{m}$ and $d(0.9)$ $=86.0 \mu \mathrm{m}$. On the other hand, ladle slag showed the largest particles with $d(0.5)=85.0 \mu \mathrm{m}$ and $d(0.9)=322.9 \mu \mathrm{m}$.

The original un-treated residues are predominantly calcium aluminosilicates whose chemical composition (determined by XRF and expressed as oxides) is shown in Table 2. It should be

Table 2

Major oxide composition (expressed as\% by weight).

\begin{tabular}{|c|c|c|c|c|c|c|c|c|c|c|c|c|c|c|}
\hline & $\mathrm{Al}_{2} \mathrm{O}_{3}$ & $\mathrm{CaO}$ & $\mathrm{Cr}_{2} \mathrm{O}_{3}$ & $\mathrm{Fe}_{2} \mathrm{O}_{3}$ & $\mathrm{~K}_{2} \mathrm{O}$ & $\mathrm{MgO}$ & $\mathrm{MnO}$ & $\mathrm{P}_{2} \mathrm{O}_{5}$ & $\mathrm{SiO}_{2}$ & $\mathrm{SO}_{3}$ & $\mathrm{TiO}_{2}$ & $\mathrm{ZnO}$ & $\mathrm{Cl}$ & LOI \\
\hline $\mathrm{APCr}$ & 0.8 & 65.0 & 0 & 0.8 & 2.0 & 1.2 & 0.2 & 0.2 & 2.5 & 12.0 & 1.95 & 2.5 & 9.8 & 0.6 \\
\hline CBD & 2.8 & 68.0 & 0 & 2.6 & 4.8 & 0.8 & 0.1 & 0.1 & 7.7 & 9.3 & 0.2 & 0 & 3.0 & 0.4 \\
\hline Steel Slag & 5.5 & 51.0 & 5.0 & 5.1 & 0.1 & 13.5 & 1.7 & 0 & 16.0 & 0.35 & 0.8 & 0.05 & 0 & 0.75 \\
\hline CEM 1 & 3.8 & 70.0 & 0 & 3.15 & 0.60 & 1.3 & 0 & 0.25 & 16.5 & 3.8 & 0.3 & 0 & 0 & 0.2 \\
\hline
\end{tabular}

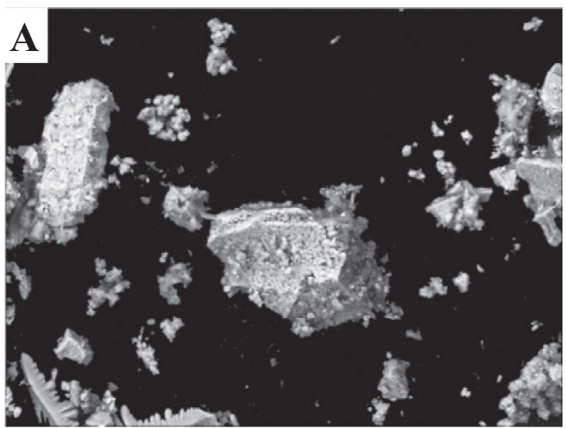

$100 \mu \mathrm{m}$

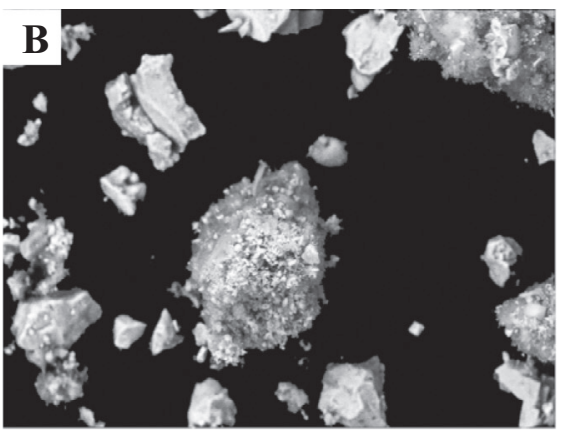

$100 \mu \mathrm{m}$

CEM 1

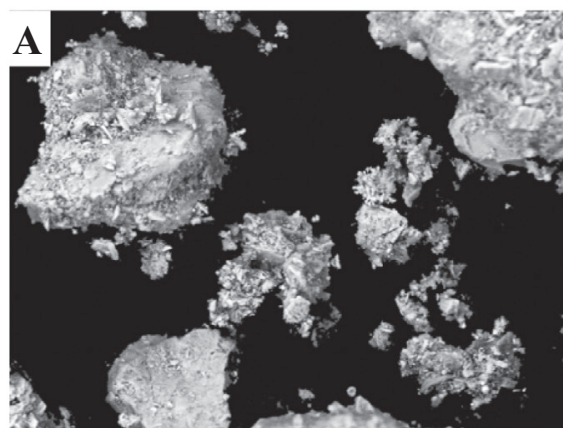

$100 \mu \mathrm{m}$

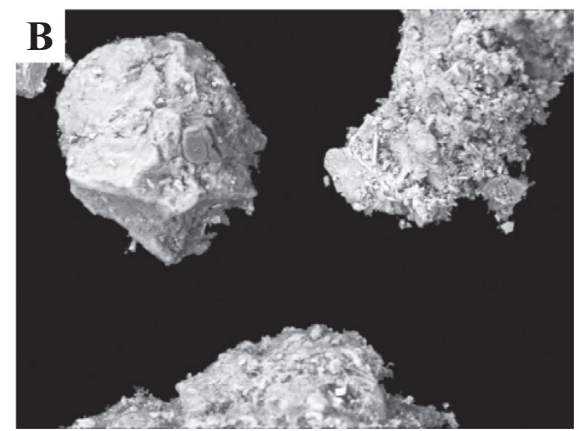

$100 \mu \mathrm{m}$

Steel slag

Fig. 2. SEM images for (A) non-sonicated and (B) sonicated CEM $1(\mathrm{w} / \mathrm{s}=100$ and $t=1 \mathrm{~h})$ and steel slag $(\mathrm{w} / \mathrm{s}=50$ and $t=1 \mathrm{~h})$. 
noted that APCr and CBD contained high levels of sulphate, while a significant concentration of magnesium was found in steel-slag.

Although no crystalline reaction products were identified, scanning electron imaging revealed differences between sonicated and non-sonicated samples, which were more evident in the particles of CEM 1 and steel-slag (Fig. 2). The sonicated particles which showed a lower $d(0.5)$ as described later in Section 2.3, exhibited also a more rounded appearance compared to non-sonicated ones that characterised by a more angular shape. Finally, analysis by SEM did not show any major fracturing of large crystals into smaller pieces by sonication as suggested by previous workers who used lower frequency $(=20 \mathrm{kHz})$, and thus higher intensity, ultrasonic probes (Price et al., 2010; Santos et al., 2013a). It seems that the main mechanism of this study is de-aggregation of particles and mixing improvement rather than particle abrasion or breakage.

\subsection{Accelerated carbonation}

Initially, the mixes were treated by accelerated carbonation for one hour and the achieved $\mathrm{CO}_{2}$ uptakes are shown in Fig. 3.

The $\mathrm{CO}_{2}$ uptake for all the input materials was dependent upon the water content. Low $\mathrm{w} / \mathrm{s}$ ratio samples $(\mathrm{w} / \mathrm{s}=0.2-0.6)$ showed high reactivity to $\mathrm{CO}_{2}$, whereas the $\mathrm{CO}_{2}$ uptake of intermediate samples $(\mathrm{w} / \mathrm{s}=0.8-10)$ was relatively weak. The reaction yield started to rise again as more water were added into the system $(\mathrm{w} / \mathrm{s}=25-100)$. The results were in accordance with previous studies, which indicated that accelerated carbonation is favoured under dry conditions (Fernandez Bertos et al., 2004), while excess water inhibits the reaction because $\mathrm{CO}_{2}$ diffusion is restricted due to pore-blocking ( Li et al., 2007). However, a further increase in water improves the reaction efficiency. It seems that the increased volume of water provides a reservoir with a larger total capacity for carbon dioxide solution and ionisation/hydration. Another explanation might be the absence of agitation that could have improved the carbonation efficiency of intermediate and high $\mathrm{w} / \mathrm{s}$ samples.

The highest $\mathrm{CO}_{2}$ uptake was shown by $\mathrm{APCr}$ at $13.3 \%$ and $\mathrm{w} / \mathrm{s}=0.4$. Compared to previous studies conducted under ambient temperature and pressure, the achieved $\mathrm{CO}_{2}$ uptake was higher than the uptake during the carbonation of Chinese $\mathrm{APCr}$ $\left(\mathrm{CO}_{2}=12 \%\right)$ in a glass cylinder ( $1000 \mathrm{ml}$ volume) (Wang et al., 2010), but lower than the $\mathrm{CO}_{2}$ uptake achieved during the carbonation of Sardinian $\operatorname{APCr}\left(\mathrm{CO}_{2}=20 \%\right)$ in an open vessel, although the reactions lasted for $3 \mathrm{~h}$ (Cappai et al., 2012). The second highest $\mathrm{CO}_{2}$ uptake was given by $\mathrm{CBD}$ at $12.9 \%$ and $\mathrm{w} / \mathrm{s}=0.6$, validating the findings of previous workers who carbonated landfilled cement dusts in columns containing $\mathrm{CO}_{2}$ and water and estimated the $\mathrm{CO}_{2}$ uptake at $11.5 \%$ (Huntzinger et al., 2009b). Steel-slag showed the lowest $\mathrm{CO}_{2}$ uptake at $6.7 \%$ and at $\mathrm{w} / \mathrm{s}=0.2$. A former study suggested that under ambient temperature and pressure the direct
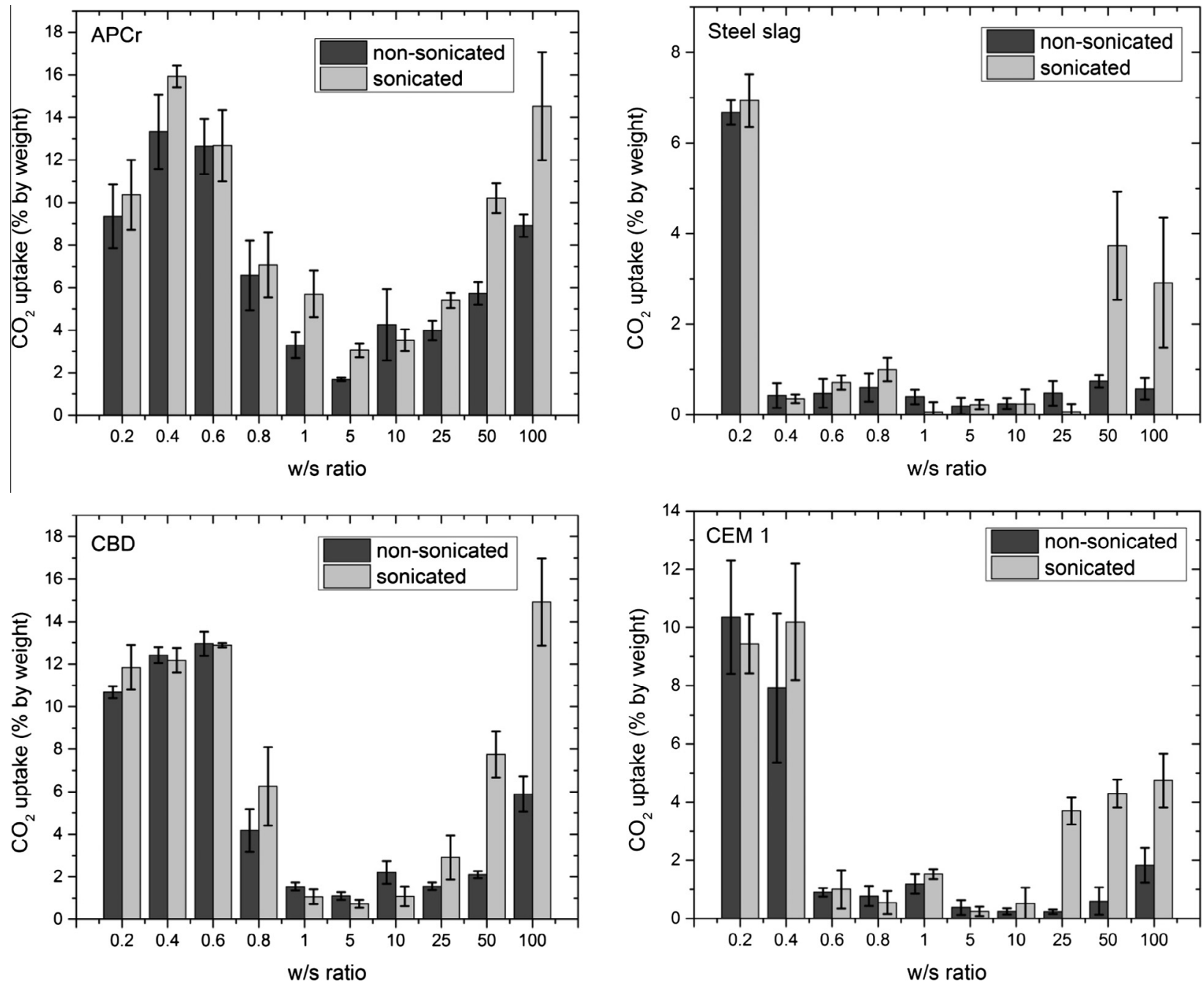

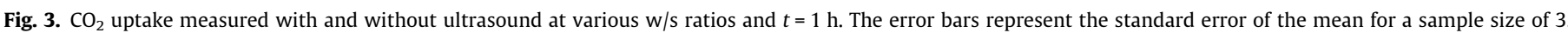


Table 3

Comparison of current with previous carbonation studies conducted under ambient $T$ and $P$.

\begin{tabular}{|c|c|c|c|c|c|c|c|c|}
\hline Waste & Major Oxides (\%) & Key minerals & Particle size $(\mu \mathrm{m})$ & Reactor type & $\mathrm{w} / \mathrm{s}$ ratio & Time $(\mathrm{h})$ & $\mathrm{CO}_{2}$ Uptake (\%) & Ref \\
\hline $\mathrm{APCr}$ & $\mathrm{n} / \mathrm{a}$ & $\begin{array}{l}\text { - Calcite } \\
\text { - Halite } \\
\text { - Portlandite } \\
\text { - Sylvite } \\
\text { - } \mathrm{Ca}(\mathrm{OH}) \mathrm{Cl}\end{array}$ & $\mathrm{n} / \mathrm{a}$ & Open Vessel & 2.5 & 4 & 20 & Cappai et al. (2012) \\
\hline $\mathrm{APCr}$ & $\begin{array}{l}\mathrm{CaO}=53.0 \\
\mathrm{Na}_{2} \mathrm{O}=5.7 \\
\mathrm{~K}_{2} \mathrm{O}=5.4 \\
\mathrm{SO}_{3}=5.1 \\
\mathrm{Cl}=18.8\end{array}$ & $\begin{array}{l}\text { - Anhydrite } \\
\text { - Calcite } \\
\text { - Halite } \\
\text { - Portlandite } \\
\text { - Quartz } \\
\text { - Sylvite }\end{array}$ & $0.14-632$ & Glass Cylinder & 0.25 & 240 & 12 & Wang et al. (2010) \\
\hline $\mathrm{APCr}$ & $\begin{array}{l}\mathrm{CaO}=65.0 \\
\mathrm{SO}_{3}=12.0 \\
\mathrm{SiO}_{2}=2.5 \\
\mathrm{Cl}=9.8\end{array}$ & $\begin{array}{l}\text { - Anhydrite } \\
\text { - Calcite } \\
\text { - Halite } \\
\text { - Lime } \\
\text { - Portlandite } \\
\text { - } \mathrm{Ca}(\mathrm{OH}) \mathrm{Cl}\end{array}$ & $<120$ & Sealed plastic tubes & 0.4 & 1 & 14.5 & This study \\
\hline Cement Dust & $\begin{array}{l}\mathrm{CaO}=34.5 \\
\mathrm{SiO}_{2}=13.1 \\
\mathrm{~K}_{2} \mathrm{O}=5.8 \\
\mathrm{SO}_{3}=4.7\end{array}$ & $\begin{array}{l}\text { - Anhydrite } \\
\text { - Arcanite } \\
\text { - Calcite } \\
\text { - Ettringite } \\
\text { - Quartz }\end{array}$ & $\mathrm{n} / \mathrm{a}$ & $\mathrm{CO}_{2} /$ Water Column & $\mathrm{n} / \mathrm{a}$ & 82 & 11.5 & Huntzinger et al. (2009a,b) \\
\hline Cement Dust & $\begin{array}{l}\mathrm{CaO}=68.0 \\
\mathrm{SO}_{3}=9.3 \\
\mathrm{SiO}_{2}=7.7 \\
\mathrm{~K}_{2} \mathrm{O}=7.8\end{array}$ & $\begin{array}{l}\text { - Anhydrite } \\
\text { - Calcite } \\
\text { - Lime } \\
\text { - Portlandite } \\
\text { - Quartz }\end{array}$ & $<120$ & Sealed plastic tubes & 0.4 & 1 & 12.9 & This study \\
\hline Ladle slag & $\begin{array}{l}\mathrm{CaO}=58.1 \\
\mathrm{SiO}_{2}=26.4 \\
\mathrm{MgO}=6.2 \\
\mathrm{Al}_{2} \mathrm{O}_{3}=4.6\end{array}$ & $\mathrm{n} / \mathrm{a}$ & $160-315$ & Pyrex Flask & 0.4 & 40 & 24.7 & Bonenfant et al. (2008) \\
\hline Ladle slag & $\begin{array}{l}\mathrm{CaO}=42.2 \\
\mathrm{Al}_{2} \mathrm{O}_{3}=22.3 \\
\mathrm{SiO}_{2}=15.02 \\
\mathrm{MgO}=14.9\end{array}$ & $\begin{array}{l}\text { - Calcite } \\
\text { - Periclase } \\
\text { - } \mathrm{Ca}_{2} \mathrm{SiO}_{4} \\
\text { - Akermanite } \\
\text { - Mayenite }\end{array}$ & $<100$ & Batch Reactor & 100 & 1.1 & 4.6 & Uibu et al. (2011) \\
\hline Ladle Slag & $\begin{array}{l}\mathrm{CaO}=51.0 \\
\mathrm{SiO}_{2}=16.0 \\
\mathrm{MgO}=13.5 \\
\mathrm{Al}_{2} \mathrm{O}_{3}=5.5 \\
\mathrm{Fe}_{2} \mathrm{O}_{3}=5.0 \\
\mathrm{CrO}_{2}=5.0\end{array}$ & $\begin{array}{l}\text { - Brucite } \\
\text { - Calcite } \\
\text { - Chromite } \\
\text { - Merwinite } \\
\text { - Periclase } \\
\text { - Portlandite } \\
\text { - Quartz }\end{array}$ & $<120$ & Sealed plastic tubes & 0.2 & 1 & 6.9 & This study \\
\hline BOF Slag & $\begin{array}{l}\mathrm{CaO}=42.4 \\
\mathrm{Fe}_{2} \mathrm{O}_{3}=26.7 \\
\mathrm{MgO}=9.15 \\
\mathrm{SiO}_{2}=12.00\end{array}$ & $\begin{array}{l}\text { - Brownmillerite } \\
\text { - } \mathrm{CaCO}_{3} \text { (pure) } \\
\text { - Lime } \\
\text { - Magnesite } \\
\text { - Olivine } \\
\text { - Quartz }\end{array}$ & $<63$ & Rotating Packed Bed & 20 & 0.5 & $93.5^{\mathrm{a}}$ & Chang et al. (2012) \\
\hline BOF Slag & $\begin{array}{l}\mathrm{CaO}=41.1 \\
\mathrm{Fe}_{2} \mathrm{O}_{3}=24.4 \\
\mathrm{SiO}_{2}=10.5 \\
\mathrm{MgO}=9.2\end{array}$ & $\begin{array}{l}\text { - Brownmillerite } \\
\text { - Calcite } \\
\text { - Hematite } \\
\text { - Lime }\end{array}$ & $<44$ & Glass Column & 20 & 2 & 28.3 & Chang et al. (2013) \\
\hline BOF Slag & $\begin{array}{l}\mathrm{SiO}_{2}=35.6 \\
\mathrm{CaO}=23.9 \\
\mathrm{Fe}_{2} \mathrm{O}_{3}=19.6\end{array}$ & $\begin{array}{l}\text { - Brucite } \\
\text { - Calcite } \\
\text { - Larnite } \\
\text { - Magnetite } \\
\text { - Portlandite }\end{array}$ & $<125$ & Open Granulator & 0.12 & 2 & 14.4 & Morone et al. (2014) \\
\hline
\end{tabular}

${ }^{a}$ Refers to carbonation conversion (\%) of steel-slag and not $\mathrm{CO}_{2}$ uptake.

aqueous carbonation of ladle slag $(\mathrm{w} / \mathrm{s}$ ratio $=10)$ in an stirred batched reactor for $40 \mathrm{~h}$ gave $\mathrm{CO}_{2}$ uptake at 24.7\% (Bonenfant et al., 2008). In another study, (Uibu et al., 2011) the $\mathrm{CO}_{2}$ uptake after direct carbonation of wet slurries $(w / s=100)$ of ladle slag inside a batch reactor for 65 min was estimated at 4.6\%. Finally, the $\mathrm{CO}_{2}$ uptake of CEM 1 was estimated at $10.3 \%$ at $\mathrm{w} / \mathrm{s}=0.2$.

The different reactivity to $\mathrm{CO}_{2}$ of the input materials could be explained by their initial concentration in calcium oxide and the mineral phases in which calcium was present (Gunning et al., 2010). According to the elemental analysis (Table 2) APCr and CBD contained high concentration of calcium (65\% and $68 \%$ respectively). Also, analysis by XRD (Fig. 6) revealed the presence of the reactive Ca-based mineral lime, which was converted into $\mathrm{CaCO}_{3}$ during carbonation. On the other hand, the concentration of calcium oxide in steel-slag was lower (51\%) and no lime was identified. High calcium content and presence of lime could also 


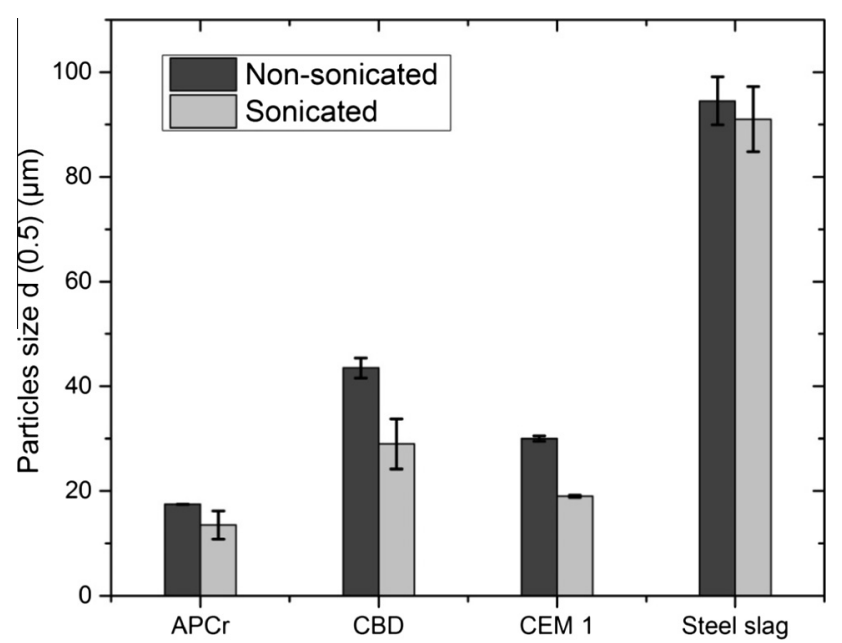

Fig. 4. Particle size $d(0.5)$ for non-sonicated and sonicated $\mathrm{APCr}(\mathrm{w} / \mathrm{s}=100), \mathrm{CBD}$ $(\mathrm{w} / \mathrm{s}=100)$, CEM $1(\mathrm{w} / \mathrm{s}=100)$ and steel slag $(\mathrm{w} / \mathrm{s}=50)$.
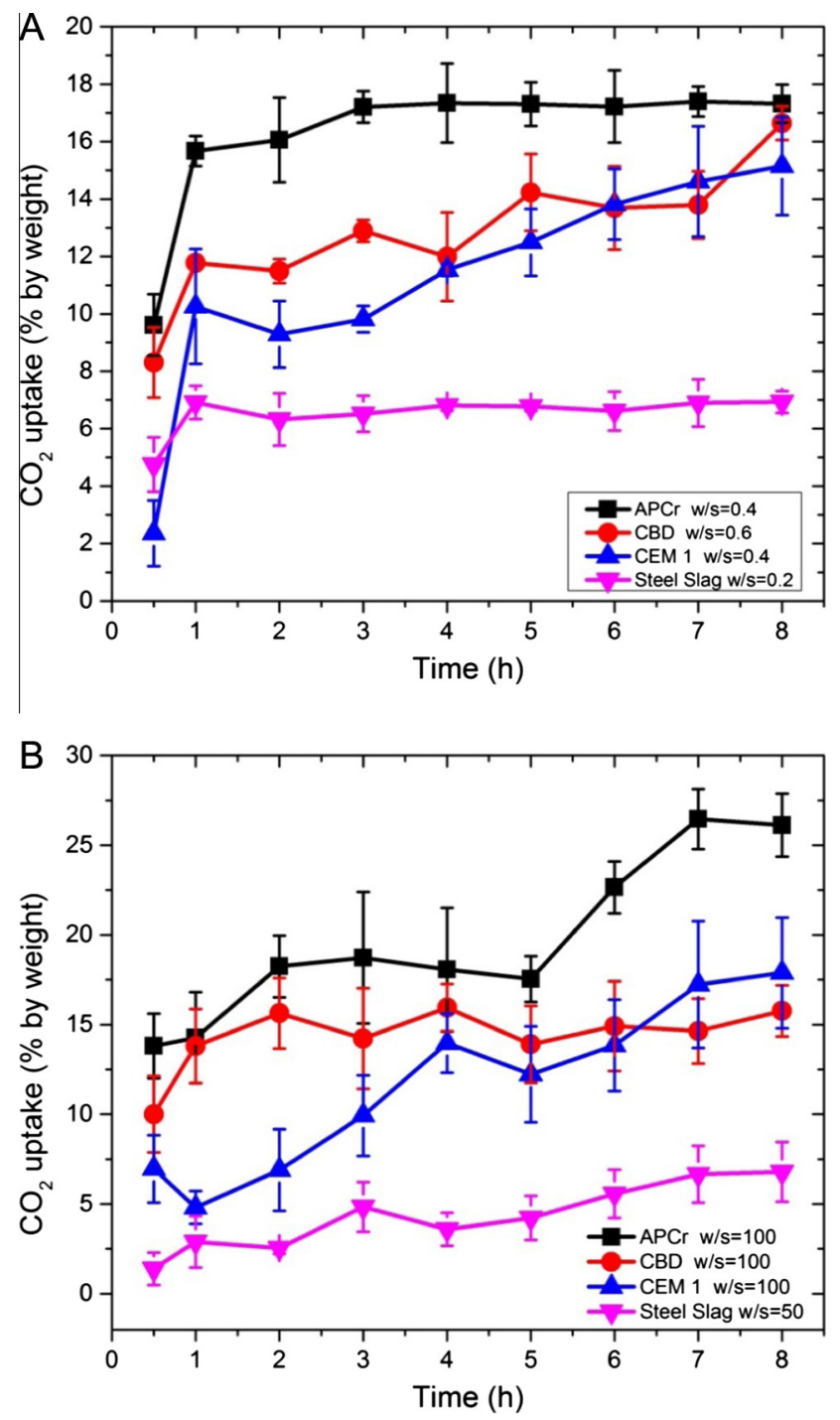

Fig. 5. Effect of sonication and carbonation time on $\mathrm{CO}_{2}$ uptake at (A) low w/s ratio and (B) high $\mathrm{w} / \mathrm{s}$ ratio. The error bars represent the standard error of the mean for a sample size of 3 . explain the improved reactivity of APCr and CBD in a wide range of water concentrations (especially for w/s ratio between 0.4 and 25 ) compared to steel-slag and CEM 1.

\subsection{Sonication at $35 \mathrm{kHz}$ for $1 \mathrm{~h}$}

The same mixes were sonicated at $35 \mathrm{kHz}$ for $1 \mathrm{~h}$ and the new $\mathrm{CO}_{2}$ uptakes were measured and compared with the uptakes achieved without ultrasound (see Fig. 3). The results showed that sonication increased the average $\mathrm{CO}_{2}$ uptake of the products by $4-28 \%$ for low and by $62-400 \%$ for high $\mathrm{w} / \mathrm{s}$ ratio samples. At intermediate $\mathrm{w} / \mathrm{s}$ ratios the yield recorded was low.

The effect of ultrasound on the $\mathrm{CO}_{2}$ uptake of low w/s ratio samples was weak, as generally too little water was available to facilitate cavitation. At $\mathrm{w} / \mathrm{s}=0.4$, the $\mathrm{CO}_{2}$ uptake of $\mathrm{APCr}$ was measured at $15.9 \%$ showing an average increase of $19.4 \%$ compared to the non-sonicated samples. At the same w/s ratio, the $\mathrm{CO}_{2}$ uptake of CEM 1 was estimated at $10.1 \%$ (average increase $28.4 \%$ ), while no change in the reaction efficiency was observed for CBD. At w/ $\mathrm{s}=0.2$ the $\mathrm{CO}_{2}$ uptake of steel-slag was estimated at $6.9 \%$ indicating a slight average increase due to sonication (4\%). In Table 3 the $\mathrm{CO}_{2}$ uptakes achieved after $1 \mathrm{~h}$ of sonication are compared with previous carbonation studies conducted at ambient conditions.

At high $\mathrm{w} / \mathrm{s}$ ratio, the conditions for sonication were much improved as more $\mathrm{CO}_{2}$ was available to the aqueous medium (Rao et al., 2007). It should be noted that the lack of agitation during sonication of wet slurries may affected the maximum possible efficiency.

The $\mathrm{CO}_{2}$ uptake of $\mathrm{APCr}$ increased by $63 \%$ and estimated at $14.5 \%(\mathrm{w} / \mathrm{s}=100)$, while the uptake of $\mathrm{CBD}$ (at $\mathrm{w} / \mathrm{s}=100)$ was measured at $14.9 \%$ suggesting an average increase of $153 \%$. The sonicated slurries $(\mathrm{w} / \mathrm{s}=100)$ of CEM 1 gave uptake at $4.7 \%$ (increased by $159 \%$ ). The biggest improvement of sonication on the reaction efficiency (increased by $400 \%$ ) was shown by steelslag and the $\mathrm{CO}_{2}$ uptake was estimated at $3.7 \%$ and $\mathrm{w} / \mathrm{s}=50$.

Evidence of the beneficial effects of ultrasound on carbonation of wet slurries of steel-slag was also found in previous studies.

Sonication of agitated wet slurries $(\mathrm{w} / \mathrm{s}=100)$ of stainless steelslag in a glass beaker for $1 \mathrm{~h}$ by using a $24 \mathrm{kHz}$ ultrasonic probe, increased the yield of carbonate in steel-slag by $2.8-8.1 \%$ (Santos et al., 2011). In addition, the sonication of agitated steelmaking slag slurries $(\mathrm{w} / \mathrm{s}=50)$ in a glass flask by using an ultrasonic bath ( $40 \mathrm{kHz}$ and $80 \mathrm{~W}$ ), enhanced the extraction of calcium from the residue especially for the smallest particles (96\% extraction compared to 65\% extracted by mechanical agitation) (Said et al., 2015).

Finally, the application of ultrasound on fluidised bed combustion ashes by using 2 different ultrasonic probes (power rating $600 \mathrm{~W}$ and $750 \mathrm{~W}$ respectively) ameliorated the carbonation rate by increasing the conversion of $\mathrm{Ca}(\mathrm{OH})_{2}$ into calcium carbonate (Rao et al., 2007).

The particle size of the sonicated slurries was lower compared to the non-sonicated ones (Fig. 4) in accordance with previous findings (Lu et al., 2002; Rao et al., 2007; Kojima et al., 2010; Santos et al., 2010, 2013a). The average median diameter $d(0.5)$ of cement particles reduced by $35.5 \%$, followed by the particles of CBD (33.5\%) and APCr (24\%). The particle size of steel-slag decreased only slightly (3\%).

\subsection{Effect of sonication time on $\mathrm{CO}_{2}$ Uptake}

For each residue, the samples that showed the highest $\mathrm{CO}_{2}$ uptake were sonicated over a prolonged time (up to $8 \mathrm{~h}$ and up to $0.96 \mathrm{kWh}$ ) in order to determine when sonication stops progressing. Accelerated carbonation is known to proceed rapidly and the reaction can be completed within hours or even minutes (Maries, 2008). In the case of $\mathrm{APCr}$ and steel-slag, analysis of 
Table 4

$\mathrm{CO}_{2}$ uptakes recorded in this study.

\begin{tabular}{|c|c|c|c|c|}
\hline Material & $\mathrm{w} / \mathrm{s}$ ratio & $\begin{array}{l}\mathrm{CO}_{2} \text { Uptake }^{\mathrm{a}} \text { after } \\
1 \mathrm{~h} \text { of } \mathrm{AC}\end{array}$ & $\begin{array}{l}\mathrm{CO}_{2} \text { Uptake }^{\mathrm{a}} \text { after } \\
1 \mathrm{~h} \text { of sonication }\end{array}$ & $\begin{array}{l}\mathrm{CO}_{2} \text { Uptake }^{\mathrm{a}} \text { after } \\
8 \mathrm{~h} \text { of sonication }\end{array}$ \\
\hline $\mathrm{APCr}$ & 0.4 & $13.3 \pm 1.7$ & $15.9 \pm 0.5$ & $17.3 \pm 1.1$ \\
\hline $\mathrm{APCr}$ & 100 & $8.9 \pm 0.5$ & $14.5 \pm 2.5$ & $26.1 \pm 3.0$ \\
\hline CBD & 0.6 & $12.9 \pm 0.5$ & $12.9 \pm 0.1$ & $16.6 \pm 0.3$ \\
\hline CBD & 100 & $5.9 \pm 0.8$ & $14.9 \pm 2.0$ & $15.7 \pm 1.4$ \\
\hline Steel slag & 0.2 & $6.6 \pm 0.2$ & $6.91 \pm 0.5$ & $6.93 \pm 0.3$ \\
\hline Steel slag & 50 & $0.7 \pm 0.1$ & $3.7 \pm 1.1$ & $6.7 \pm 1.6$ \\
\hline CEM 1 & 0.4 & $7.9 \pm 2.5$ & $10.1 \pm 2.0$ & $15.1 \pm 1.7$ \\
\hline CEM 1 & 100 & $1.8 \pm 0.5$ & $4.7 \pm 0.9$ & $17.8 \pm 3.0$ \\
\hline
\end{tabular}

a $\mathrm{CO}_{2}$ uptake is expressed as\% by weight.

Fig. 5A led to the same conclusion, as the reaction reached a plateau after one hour of sonication. The results for CBD and CEM 1 showed that the $\mathrm{CO}_{2}$ uptake stopped increasing after five and six hours respectively.

The higher concentration of water in the sonicated samples resulted in a slower reaction and inhibited the rapid diffusion of $\mathrm{CO}_{2}$ into the system (Fig. 5B). The only exception was observed for $\mathrm{CBD}$, where the reaction rate stopped progressing after two hours of treatment. For the other materials, the recorded $\mathrm{CO}_{2}$ uptake was increasing continuously and only after seven hours of sonication remained at a relatively stable level. Considering that longer sonication time $(>1 \mathrm{~h})$ did not considerably increase the $\mathrm{CO}_{2}$ capture capacity of the waste residues, the application of ultrasound for more than $1 \mathrm{~h}$ is not cost-effective and it is not recommended for use at large scale.

Table 4 summarises the $\mathrm{CO}_{2}$ uptakes recorded for $1 \mathrm{~h}$ of treatment (with and without sonication) and after $8 \mathrm{~h}$ of sonication, as well as the optimum $\mathrm{w} / \mathrm{s}$ ratios for each of the tested materials.

\subsection{Phase analysis by X-ray diffraction}

The key mineral phases of the original, sonicated and nonsonicated materials (at high $\mathrm{w} / \mathrm{s}$ ratio and one hour of treatment) are shown in Fig. 6. Calcite was found in all the un-treated residues indicating carbonation prior to treatment (Huntzinger et al., 2009b). For APCr and CBD, the application of ultrasound resulted in the full carbonation of lime and portlandite.

The composition of APCr is very diverse, depending on the type of incineration feed that typically includes metals, plastic and putrescent materials (Arickx et al., 2006). In this study, the untreated ashes composed of many Ca- and Cl-based mineral phases such as lime, portlandite, halite and calcium chloride hydroxide. The mineral analysis of $\mathrm{APCr}$ revealed the presence of vaterite in the carbonated products. Vaterite is the least thermodynamically stable polymorph of $\mathrm{CaCO}_{3}$ and when exposed to water, is transformed into either calcite or aragonite (Price et al., 2010). After sonication, the peak intensity of calcite increased due to the complete carbonation of lime and portlandite as they both showed no signals of detection. On the other hand, the diffractogram of the non-sonicated ashes revealed the presence of un-reacted portlandite. The mineral $\mathrm{Ca}(\mathrm{OH}) \mathrm{Cl}$ was not identified after treatment. $\mathrm{Ca}(\mathrm{OH}) \mathrm{Cl}$ is highly soluble and it is also likely to participate in complex reactions which form minor chloride-based mineral phases (Wang et al., 2010).

CBDs are formed during cement manufacture, after kiln firing (Gunning et al., 2010), at high temperature (around $1400^{\circ} \mathrm{C}$ ) and for this reason their chemistry was rich in calcium contents (lime, portlandite and calcite) and sulphur present as anhydrous calcium sulphate (anhydrite). During sonication, lime and portlandite totally reacted to form $\mathrm{CaCO}_{3}$, while un-reacted concentrations of these minerals were detected in the non-sonicated samples.
It is known that the mineral composition of steel-slag is complex including several mineral phases (Baciocchi et al., 2015). Steel-slag is the main by-product of steel production process, comprising calcium, iron, aluminium, magnesium, manganese and other heavy metals. Due to its high alkalinity (high $\mathrm{pH}$ ) intensive pre-treatment prior to disposal or valorisation is required (Santos et al., 2013b). The predominant mineral phases of steel-slag were the minerals brucite, calcite, chromite, merwinite, periclase, portlandite and quartz. The element chromium was present as chromite that belongs to the spinel group. Analysis by XRD showed that the peaks intensity of portlandite in the sonicated and nonsonicated slags decreased, while the peaks of calcite increased. It seems that a portion of portlandite reacted with $\mathrm{CO}_{2}$ and formed calcite.

CEM 1 was primarily composed of calcium present as calcite and, along with silicon, as the calcium silicates hatruite and larnite. The high concentration of calcium (70\%) found in the un-treated CEM 1 is not unusual, as Portland cement contains remarkable amounts of calcium ions (Otieno et al., 2014; Thomas et al., 2012). Also sulphate was bound in the mineral gypsum. The diffractograms of both sonicated and non-sonicated CEM 1 showed more intense peaks of calcite compared to original CEM 1. A possible explanation was given by previous workers that observed the breakdown of di-calcium silicates and the formation of calcite during carbonation (Fernandez Bertos et al., 2004).

\section{Conclusions}

This study investigated the possibility of enhancing the accelerated carbonation of APCr, CBD and ladle slag by ultrasound via a $\mathrm{CO}_{2}$ negative process with an estimated energy consumption of $0.12 \mathrm{kWh}$. Sonication was favoured at high w/s ratios (50-100), increasing the reaction efficiency by $65-400 \%$. At low $\mathrm{w} / \mathrm{s}$ ratio (0.2-0.6), although the $\mathrm{CO}_{2}$ uptake was higher compared to wet slurries (for APCr at $15.9 \%, \mathrm{CBD}$ at $12.9 \%$ and ladle slag at $6.91 \%$ ), the effect of ultrasound was weak due to the lack of enough water to facilitate cavitation. Sonication decreased the particle size of the newly formed carbonated products, which exhibited a more rounded appearance. Finally, analysis by XRD showed that sonication enhanced the full conversion of lime and portlandite into calcite.

Despite the fact that ultrasound did not significantly increase the $\mathrm{CO}_{2}$ uptake of the treated materials, the reactivity of wet slurries under temperature and pressure was improved. Ambient conditions are desirable during the handling or processing of vast amounts of residues, since the associated costs are kept to a minimum. Thus, sonication should be considered as a potential way of increasing the carbon sequestration capacity of industrial wastes treated by accelerated carbonation.

It should be noted that this is a preliminary study and the effect of frequency/intensity and the power of the sonication device on 

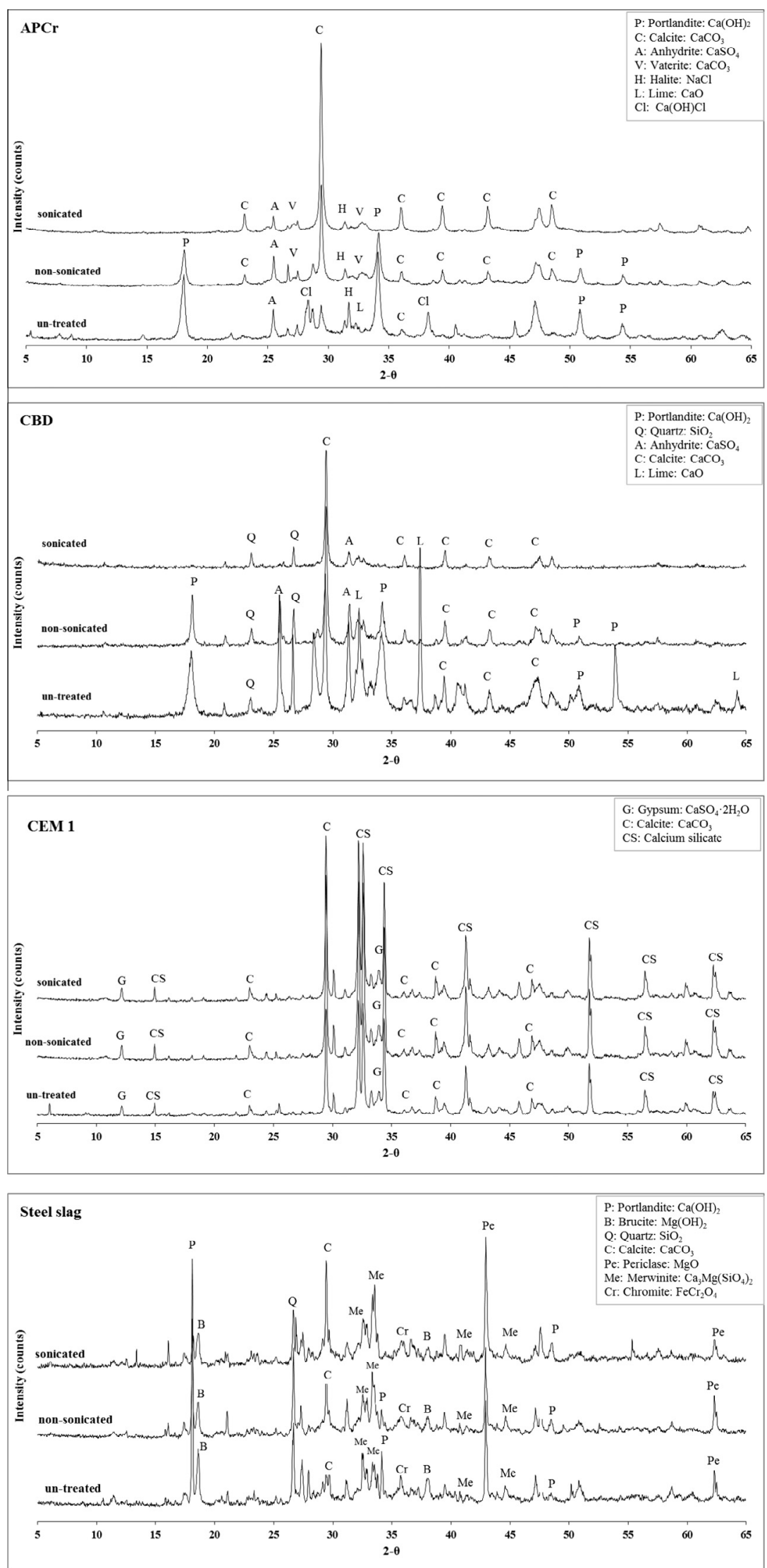

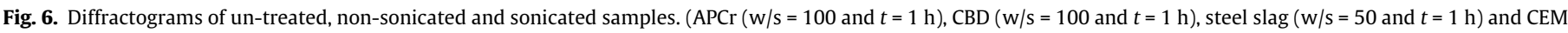
$1(\mathrm{w} / \mathrm{s}=100$ and $t=1 \mathrm{~h}))$. 
the $\mathrm{CO}_{2}$ uptake remains to be addressed. It is anticipated that the exposure of alkaline wastes to a higher power (power rating $>150 \mathrm{~W})$ or lower frequency $(<35 \mathrm{kHz}) /$ higher intensity, may increase their reactivity to carbon dioxide during treatment. However, future research should be accompanied by a detailed cost and energy consumption analysis that will determine the feasibility of any ultrasound-based process at large scale.

\section{Acknowledgments}

This study was carried out as part of a Ph.D. supported by the Faculty of Engineering and Science, University of Greenwich. The corresponding author would like to acknowledge the support and advice of Dr Nikolaos Scoutaris (University of Greenwich).

\section{References}

Arickx, S., van Gerven, T., Vandecasteele, C., 2006. Accelerated carbonation for treatment of MSWI bottom ash. J. Hazard. Mater. 137, 235-243.

Baciocchi, R., Costa, G., di Bartolomeo, E., Polettini, A., Pomi, R., 2009. The effects of accelerated carbonation on $\mathrm{CO}_{2}$ uptake and metal release from incineration APC residues. Waste Manage. 29, 2994-3003.

Baciocchi, R., Costa, G., Polettini, A., Pomi, R., 2015. Effects of thin-film accelerated carbonation on steel slag leaching. J. Hazard. Mater. 286, 369-378.

Bobicki, E.R., Liu, Q., Xu, Z., Zeng, H., 2012. Carbon capture and storage using alkaline industrial wastes. Prog. Energy Combust. Sci. 38, 302-320.

Bonenfant, D., Kharoune, L., Sauvé, S., Hausler, R., Niquette, P., Mimeault, M., Kharoune, M., 2008. CO2 sequestration potential of steel slags at ambient pressure and temperature. Ind. Eng. Chem. Res. 47, 7610-7616.

Boone, M.A., Nielsen, P., de Kock, T., Boone, M.N., Quaghebeur, M., Cnudde, V., 2013. Monitoring of stainless-steel slag carbonation using X-ray computed microtomography. Environ. Sci. Technol. 48, 674-680.

Cappai, G., Cara, S., Muntoni, A., Piredda, M., 2012. Application of accelerated carbonation on MSW combustion APC residues for metal immobilization and CO2 sequestration. J. Hazard. Mater. 207-208, 159-164.

Cárdenas-Escudero, C., Morales-Flórez, V., Pérez-López, R., Santos, A., Esquivias, L. 2011. Procedure to use phosphogypsum industrial waste for mineral $\mathrm{CO}_{2}$ sequestration. J. Hazard. Mater. 196, 431-435.

Castellote, M., Andrade, C., Turrillas, X., Campo, J., Cuello, G.J., 2008. Accelerated carbonation of cement pastes in situ monitored by neutron diffraction. Cem. Concr. Res. 38, 1365-1373.

Chang, E.E., Chiu, A.-C., Pan, S.-Y., Chen, Y.-H., Tan, C.-S., Chiang, P.-C., 2013 Carbonation of basic oxygen furnace slag with metalworking wastewater in a slurry reactor. Int. J. Greenhouse Gas Control 12, 382-389.

de Ceukelaire, L., van Nieuwenburg, D., 1993. Accelerated carbonation of a blastfurnace cement concrete. Cem. Concr. Res. 23, 442-452.

Fernandez Bertos, M., Li, X., Simons, S.J.R., Hills, C.D., Carey, P.J., 2004. Investigation of accelerated carbonation for the stabilisation of MSW incinerator ashes and the sequestration of $\mathrm{CO}_{2}$. Green Chem. 6, 428-436.

Franco, F., Pérez-Maqueda, L.A., Pérez-Rodríguez, J.L., 2004. The effect of ultrasound on the particle size and structural disorder of a well-ordered kaolinite. J. Colloid Interface Sci. 274, 107-117.

Goñi, S., Guerrero, A., 2003. Accelerated carbonation of Friedel's salt in calcium aluminate cement paste. Cem. Concr. Res. 33, 21-26.

Gunning, P.J., Hills, C.D., Carey, P.J., 2009. Production of lightweight aggregate from industrial waste and carbon dioxide. Waste Manage. 29, 2722-2728.

Gunning, P.J., Hills, C.D., Carey, P.J., 2010. Accelerated carbonation treatment of industrial wastes. Waste Manage. 30, 1081-1090.

Huijgen, W.J.J., Comans, R.N.J., 2005. Mineral $\mathrm{CO}_{2}$ sequestration by steel slag carbonation. Environ. Sci. Technol. 39, 9676-9682.

Huntzinger, D.N., Gierke, J.S., Kawatra, S.K., Eisele, T.C., Sutter, L.L., 2009a. Carbon dioxide sequestration in cement kiln dust through mineral carbonation. Environ. Sci. Technol. 43, 1986-1992.

Huntzinger, D.N., Gierke, J.S., Sutter, L.L., Kawatra, S.K., Eisele, T.C., 2009b. Mineral carbonation for carbon sequestration in cement kiln dust from waste piles. J. Hazard. Mater. 168, 31-37.

Kirchofer, A., Becker, A., Brandt, A., Wilcox, J., 2013. $\mathrm{CO}_{2}$ mitigation potential of mineral carbonation with industrial alkalinity sources in the United States. Environ. Sci. Technol. 47, 7548-7554.

Kojima, Y., Yamaguchi, K., Nishimiya, N., 2010. Effect of amplitude and frequency of ultrasonic irradiation on morphological characteristics control of calcium carbonate. Ultrason. Sonochem. 17, 617-620.

Li, X., Bertos, M.F., Hills, C.D., Carey, P.J., Simon, S., 2007. Accelerated carbonation of municipal solid waste incineration fly ashes. Waste Manage. 27, 1200-1206.
López-Periago, A.M., Pacciani, R., García-González, C., Vega, L.F., Domingo, C., 2010. A breakthrough technique for the preparation of high-yield precipitated calcium carbonate. J. Supercritical Fluids 52, 298-305.

López-Periago, A.M., Pacciani, R., Vega, L.F., Domingo, C., 2011. Monitoring the effect of mineral precursor, fluid phase $\mathrm{CO}_{2}-\mathrm{H}_{2} \mathrm{O}$ composition, and stirring on $\mathrm{CaCO}_{3}$ crystallization in a supercritical-ultrasound carbonation process. Cryst. Growth Des. 11, 5324-5332.

Lu, Y., Riyanto, N., Weavers, L.K., 2002. Sonolysis of synthetic sediment particles: particle characteristics affecting particle dissolution and size reduction. Ultrason. Sonochem. 9, 181-188.

Maries, A., 2008. A sequential process model for the accelerated carbonation of Portland cement. In: 2nd International Conference on Accelerated Carbonation for Environmental and Materials Engineering (ACEME 08), Rome.

Nabhani, F., McKie, M., Hodgson, S., 2013. A case study on a sustainable alternative to the landfill disposal of spent foundry sand. Int. J. Sust. Manuf. 3, 1-19.

Nishida, I., 2004. Precipitation of calcium carbonate by ultrasonic irradiation. Ultrason. Sonochem. 11, 423-428.

Otieno, M., Beushausen, H., Alexander, M., 2014. Effect of chemical composition of slag on chloride penetration resistance of concrete. Cement Concr. Compos. 46, 56-64.

Parmesan, C., Burrows, M.T., Duarte, C.M., Poloczanska, E.S., Richardson, A.J., Schoeman, D.S., Singer, M.C., 2013. Beyond climate change attribution in conservation and ecological research. Ecol. Lett. 16, 58-71.

Pérez-López, R., Montes-Hernandez, G., Nieto, J.M., Renard, F., Charlet, L., 2008. Carbonation of alkaline paper mill waste to reduce $\mathrm{CO} 2$ greenhouse gas emissions into the atmosphere. Appl. Geochem. 23, 2292-2300.

Power, I.M., Harrison, A.L., Dipple, G.M., Wilson, S.A., Kelemen, P.B., Hitch, M., Southam, G., 2013. Carbon mineralization: from natural analogues to engineered systems. Rev. Mineral. Geochem. 77, 305-360.

Price, G.J., Mahon, M.F., Shannon, J., Cooper, C., 2010. Composition of calcium carbonate polymorphs precipitated using ultrasound. Cryst. Growth Des. 11, 39-44.

Prigiobbe, V., Polettini, A., Baciocchi, R., 2009. Gas-solid carbonation kinetics of air pollution control residues for CO2 storage. Chem. Eng. J. 148, 270-278.

Raman, V., Abbas, A., 2008. Experimental investigations on ultrasound mediated particle breakage. Ultrason. Sonochem. 15, 55-64.

Rao, A., Anthony, E.J., Jia, L., Macchi, A., 2007. Carbonation of FBC ash by sonochemical treatment. Fuel 86, 2603-2615.

Rendek, E., Ducom, G., Germain, P., 2006. Carbon dioxide sequestration in municipal solid waste incinerator (MSWI) bottom ash. J. Hazard. Mater. 128, 73-79.

Renforth, P., Washbourne, C.L., Taylder, J., Manning, D.A.C., 2011. Silicate production and availability for mineral carbonation. Environ. Sci. Technol. 45, 2035-2041.

Said, A., Mattila, O., Eloneva, S., Järvinen, M., 2015. Enhancement of calcium dissolution from steel slag by ultrasound. Chem. Eng. Process. 89, 1-8.

Sanna, A., Dri, M., Hall, M.R., Maroto-Valer, M., 2012. Waste materials for carbon capture and storage by mineralisation (CCSM) - A UK perspective. Appl. Energy 99, 545-554.

Santos, R., Ceulemans, P., François, D., Van Gerven, T., 2011. Ultrasound-enhanced mineral carbonation. The 3rd European Process Intensification Conference.

Santos, R., François, D., Vandevelde, E., Martens, G., Elsen, J., Van Gerven, T., 2010. Process intensification routes for mineral carbonation. In: 3rd International Conference on Accelerated Carbonation for Environmental and Materials Engineering (ACEME 10), 29Nov-1 Dec 2010 Turku, Finland.

Santos, R.M., Ceulemans, P., van Gerven, T., 2012. Synthesis of pure aragonite by sonochemical mineral carbonation. Chem. Eng. Res. Des. 90, 715-725.

Santos, R.M., François, D., Mertens, G., Elsen, J., van Gerven, T., 2013a. Ultrasoundintensified mineral carbonation. Appl. Therm. Eng. 57, 154-163.

Santos, R.M., van Bouwel, J., Vandevelde, E., Mertens, G., Elsen, J., van Gerven, T., 2013b. Accelerated mineral carbonation of stainless steel slags for $\mathrm{CO}_{2}$ storage and waste valorization: effect of process parameters on geochemical properties. Int. J. Greenhouse Gas Control 17, 32-45.

Shu-Yuan, P., Chang, E.E., Chiang, P.-C., 2012. $\mathrm{CO}_{2}$ capture by accelerated carbonation of alkaline wastes: a review on its principles and applications. Aerosol Air Quality Res., 770-791

Stoica-Guzun, A., Stroescu, M., Jinga, S., Jipa, I., Dobre, T., Dobre, L., 2012. Ultrasound influence upon calcium carbonate precipitation on bacterial cellulose membranes. Ultrason. Sonochem. 19, 909-915.

Thomas, M.D.A., Hooton, R.D., Scott, A., Zibara, H., 2012. The effect of supplementary cementitious materials on chloride binding in hardened cement paste. Cem. Concr. Res. 42, 1-7.

Tian, S., Jiang, J., 2012. Sequestration of flue gas CO2 by direct gas-solid carbonation of air pollution control system residues. Environ. Sci. Technol. 46, 1354513551.

Uibu, M., Kuusik, R., Andreas, L., Kirsimäe, K., 2011. The CO2 -binding by Ca-Mgsilicates in direct aqueous carbonation of oil shale ash and steel slag. Energy Procedia 4, 925-932.

Wang, L., Jin, Y., Nie, Y., 2010. Investigation of accelerated and natural carbonation of MSWI fly ash with a high content of Ca. J. Hazard. Mater. 174, 334-343.

Zhang, H., He, P.-J., Shao, L.-M., Lee, D.-J., 2008. Temporary stabilization of air pollution control residues using carbonation. Waste Manage. 28, 509-517. 